\title{
KEWENANGAN JAKSA \\ DALAM MEMULIHKAN KEKAYAAN NEGARA
}

\author{
Fatimah Albatul \\ Dusun Torbang Timur RT oo I RW 002 Torbang Batuan Sumenep | \\ fatym.imoetz@gmail.com.
}

\begin{abstract}
: this article discusses about the authority of the prosecutor in restoring the state's assets based on Undang-Undang Kejaksaan No. 16 tahun 2004. Such a constitusional authority is in the form of obtainning special authorization from the government agencies as defined in article 30 paragraph 2 of Undang-Undang Kejaksaan. The scope of the authority includes, law enforcement, legal aid, legal consideration, saving and restoring the state's wealth. In accordance with restoring the state's wealth, it can be done by filing a lawsuit in court or by offering peace outside of the court. The authority of prosecutor in restoring the state's wealth, according to the political jurisprudence, is valid in accordance with the authority of hisbah as a government official supervisor to resolve the dispute in the case of administrative irregularities. So, the prosecutor's attempt to resolve the dispute can be justified, either by the litigation or non-litigation way. Likewise, it is the hisbah which has the authority to do prosecution and call the parties to be peacefully resolved.
\end{abstract}

Keywords: Prosecutor, recovery, wealth, state, political jurisprudence.

Abstrak: Kewenangan jaksa dalam memulihkan kekayaan negara menurut Undang-undang kejaksaan No 16. Tahun 2004 adalah kewenangan dengan mendapat kuasa khusus dari instansi pemerintah atau negara, baik di dalam maupun di luar pengadilan, sebagaimana dijelaskan dalam pasal 30 ayat 2 undang-undang kejaksaan. Ruang lingkup dari kewenangan tersebut meliputi; penegakan hukum, bantuan hukum, pertimbangan hukum, menyelamatkan dan memulihkan kekayaan negara. Dalam memulihkan kekayaan negara, akibat yang ditimbulkan dari kerugian negara dapat dilakukan dengan cara mengajukan gugatan di dalam pengadilan atau dengan cara perdamaian di luar pengadilan. Kewenangan jaksa dalam memulihkan kekayaan negara menurut fikih siyasah adalah sesuai dengan 
kewenangan lembaga hisbah, sebagai pengawas pejabat pemerintah, yang bertugas untuk menyelesaikan sengketa jika terjadi penyimpangan dalam pemerintahannya. Berdasarkan hal tersebut, upaya jaksa dalam menyelesaikan sengketa dapat dibenarkan, baik dengan jalan litigasi maupun non litigasi, sebagaimana lembaga hisbah yang melakukan penuntutan dan pemanggilan para pihak untuk diselesaikan secara damai.

Kata Kunci: Jaksa, Pemulihan, Kekayaan, Negara, Fikih Siyasah

\section{Pendahuluan}

Lembaga Kejaksaan Indonesia sebagai aparatur negara mempunyai wewenang dan tugas yang berat dalam menegakkan hukum. Hal tersebut merupakan salah satu alasan dikeluarkannya UU No. 16 tahun 2004 tentang kejaksaan yang menggantikan UU No. 5 tahun 1991. Perubahan tersebut dimaksudkan untuk memantapkan fungsi dan kedudukan jaksa dalam melaksanakan kekuasaan negara, terlepas dari pengaruh kekuasaan pemerintah dan kekuasaan lainnya.

Berdasarkan perkembangan kebutuhan hukum masyarakat dan kehidupan ketatanegaraan, maka tugas jaksa semakin luas, tidak hanya dalam hal penuntutan dan pelaksanaan putusan hakim, melainkan juga bertugas dalam beberapa bidang. Wewenang jaksa sebagai aparatur negara tercantum dalam UU No. 16 tahun 2004 tentang kejaksaan. Salah satu tugas dan wewenangnya terdapat pada pasal 30: ${ }^{1}$

1. Di bidang pidana, kejaksaan mempunyai tugas dan wewenang sebagai berikut :

a. Melakukan penuntutan;

b. Melaksanakan penetapan hakim dan putusan pengadilan yang telah memperoleh kekuatan hukum tetap;

c. Melakukan pengawasan terhadap pelaksanaan putusan pidana bersyarat, putusan pidana pengawasan, dan keputusan lepas bersyarat;

' Lembaran Negara Republik Indonesia No 67 (26 Juli 2004) tentang UU Kejaksaan No. 16 Tahun 2004. 
d. Melakukan penyidikan terhadap tindak pidana tertentu berdasarkan undang- undang;

e. Melengkapi berkas perkara tertentu dan untuk itu dapat melakukan pemeriksaan tambahan sebelum dilimpahkan ke pengadilan yang dalam pelaksanaannya dikoordinasikan dengan penyidik.

2. Di bidang perdata dan tata usaha negara, kejaksaan dengan kuasa khusus dapat bertindak, baik di dalam maupun di luar pengadilan, untuk dan atas nama negara atau pemerintah.

3. Dalam bidang ketertiban dan ketenteraman umum, kejaksaan turut menyelenggarakan kegiatan:

a. Peningkatan kesadaran hukum masyarakat;

b. Pengamanan kebijakan penegakan hukum;

c. Pengawasan peredaran barang cetakan;

d. Pengawasan aliran kepercayaan yang dapat membahayakan masyarakat dan negara;

e. Pencegahan penyalahgunaan dan/atau penodaan agama;

f. Penelitian dan pengembangan hukum serta statistik kriminal.

Undang-undang tersebut juga mengatur dan mengukuhkan beberapa tugas dan wewenang jaksa lainnya, antara lain mengenyampingkan perkara demi kepentingan umum, mengefektifkan penegakan hukum yang diberikan oleh undangundang, mengajukan kasasi demi kepentingan umum kepada Mahkamah Agung dalam perkara pidana, perdata dan tata usaha negara.

Adapun ruang lingkup bidang perdata dan tata usaha negara meliputi berbagai macam fungsi yang salah satunya adalah memulihkan kekayaan negara. Dalam hal ini, ada dua penjelasan terkait pengertian dari kalimat tersebut yakni kekayaan dan negara. Adapun pengertian kekayaan adalah identik dengan harta atau benda kepemilikan, sedangkan pengertian negara adalah organisasi dalam suatu wilayah yang mepunyai kekuasaan 
tertinggi yang sah dan ditaati oleh rakyat. Jadi kekayaan negara dapat diartikan dengan harta atau benda milik negara.

Dijelaskan pula dalam Undang-undang tentang keuangan negara pasal 2 (g) mengenai kekayaan negara yakni "kekayaan negara/kekayaan daerah yang dikelola sendiri atau oleh pihak lain berupa uang, surat berharga, piutang, barang, serta hak-hak lain yang dapat dinilai dengan uang, termasuk kekayaan yang dipisahkan pada perusahaan negara/perusahaan daerah".

Peran pemerintah dan masyarakat sangat penting dalam pengelolaan kekayaan negara. Dengan melibatkan masyarakat untuk meningkatkan pemahaman tentang pentingnya pengelolaan kekayaan negara serta dalam pengawasan pengelolaan kekayaan negara, diharapkan tidak terjadi hal-hal penyelewengan kekayaan negara yang dapat merugikan negara dan masyarakat. Apabila terjadi permasalahan dalam kekayaan negara antara masyarakat dan pemerintah atau suatu lembaga, jaksa selaku aparat penegak hukum yang bertugas dalam bidang perdata dan tata usaha negara dapat diberi wewenang untuk memulihkan kekayaan negara setelah mendapat kuasa khusus dari pihak terkait.

Jaksa, setelah adanya kuasa khusus dari pihak yang bersangkutan dan untuk menangani perkara yang berkaitan dengan kekayaan negara, dapat bekerja sama dengan instansi yang berwenang untuk mengurus dan mengawasi kekayaan negara, seperti lembaga Badan Pengawas Keuangan dan Badan Pengawas Keuangan dan Pembangunan.

Dalam fikih siyasah, tidak dibahas secara spesifik tentang kewenangan jaksa dalam memulihkan kekayaan, tetapi terdapat konsep khusus tentang bait al-mal yang mengatur kekayaan negara dan al-hisbah sebagai lembaga yang mengawasi kinerja aparatur negara. Berdasarkan hal tersebut, menarik dibahas dalam artikel ini tentang kewenangan jaksa dalam memulihkan kekayaan negara ditinjau dalam perspektif fikih siyasah. 


\section{Kewenangan Jaksa dalam UU Kejaksaan dan Kekayaan Negara}

Struktur Ketatanegaraan Indonesia disusun sedemikian rupa sesuai dengan ide dan karakter tertentu yang lahir dari pengalaman dan sejarah bangsa. Dalam perkembangan ilmu hukum, hukum dapat dibagi menjadi dua, yaitu hukum privat dan hukum publik. Hukum privat merupakan hukum yang mengatur orang perorang, sedangkan hukum publik merupakan hukum yang mengatur hubungan orang dengan negara. Dalam hukum publik terdapat hukum pidana yang mempunyai sifat utama dalam pelaksanaannya tidak tergantung kepada persetujuan seorang oknum yang dirugikan oleh suatu tindak pidana melainkan diserahkan pada lembaga pemeritah terkait dengan hal tersebut. ${ }^{2}$ Istilah jaksa dalam peradilan di Indonesia dan dalam mengemban tugas nya dikenal dengan istilah jaksa penuntut umum. Istilah tersebut tercantum pula dalam perundangundangan yang berlaku di Indonesia ini.

Dengan semakin berkembangnya ranah hukum, semakin berkembang pula tugas kejaksaan Republik Indonesia, yang awalnya hanya bertugas dalam perkara pidana baik dalam penuntutan maupun dalam pelaksana putusan hakim, serta menjadi penyidik bagi pidana tertentu berdasrkan undangundang, tugas tersebut semakin bertambah dalam ranah perdata dan tata usaha negara serta dalam bidang ketertiban dan ketentraman umum bagi masyarakat dan negara.

Pada peradilan di zaman Hindia Belanda, jaksa tidaklah semata-mata berurusan dengan penuntutan perkara pidana. melainkan mempunyai ketententuan-ketentuan dalam Herzeine Indonesich Reglement (HIR) yang diperluas dengan Regerings Reglement Staadblad Tahun 1922 No 522 menyebutkan tugas jaksa, selain sebagai "officer van justitie" juga menjadi "advokaat" dan

${ }^{2}$ Djoko Prakoso, Eksistensi Jaksa di Tengah-tengah Masyarakat, (Jakarta: Ghalia Indonesia: 1985), 81. 
"lands advokat" yang mewakili kepentingan Pemerintah Hindia Belanda dalam perkara-perkara perdata. ${ }^{3}$

Mengungkap sejarah peradilan di Indonesia, jaksa yang dikenal sejak dulu, mempunyai fungsi sebagai hakim dalam perkara-perkara padu, atau sebagai hakim dalam perkara-perkara ringan, misalnya perselisihan antar masyarakat (perkara-perkara ringan tersebut dalam hukum barat disebut sebagai hukum perdata), jaksa kadang pula bertindak sebagai pembela dari orangorang yang menjadi abdi dalam kesultanan, atau dalam pengadilan harta. ${ }^{4}$ Berdasarkan undang-undang Kejaksaan No 16 tahun 2004 tugas jaksa selain dalam bidang pidana di antaranya tertera pada pasal 30 ayat 2 bahwa: "Di bidang perdata dan tata usaha negara, kejaksaan dengan kuasa khusus dapat bertindak baik di dalam maupun di luar pengadilan untuk dan atas nama negara atau pemerintah".

Tugas jaksa dalam bidang perdata dan tata usaha negara tersebut diperjelas dalam pertuaran Jaksa No 9 tahun 2011 dan Peraturan Presiden No 38 tahun 2010, tentang organisasi dan tata kerja Kejaksaan Republik Indonesia, yakni: ${ }^{5}$

(1) Jaksa Agung Muda Bidang Perdata dan Tata Usaha Negara mempunyai tugas dan wewenang melaksanakan tugas dan wewenang kejaksaan di bidang perdata dan tata usaha negara.

(2) Lingkup bidang perdata dan tata usaha negara sebagaimana dimaksud pada ayat (1) meliputi penegakan hukum, bantuan hukum, pertimbangan hukum dan tindakan hukum lain kepada negara atau pemerintah, meliputi lembaga/badan negara, lembaga/instansi pemerintah pusat dan daerah, Badan Usaha Milik Negara/Daerah di bidang perdata dan tata usaha negara untuk menyelamatkan, memulihkan kekayaan

3 Kejaksaan RI dalam http://www.kejaksaan.go.id/tentang_kejaksaan.php?id=3, diakses 15 Februari 2013.

${ }^{4}$ Djoko Prakoso, Eksistensi Jaksa di Tengah-tengah Masyarakat, 83.

${ }^{5}$ Peraturan Presiden Republik Indonesia No. 38 Tahun 2010 tentang Organisasi dan Tata Kerja Kejaksaan RI. 
negara, menegakkan kewibawaan pemerintah dan negara serta memberikan pelayanan hukum kepada masyarakat.

Jaksa dalam mengemban tugas di bidang perdata dan tata usaha negara tidak sama halnya dengan tugas di bidang pidana misalnya dalam penuntut umum, yang memang sudah menjadi tugas menuntut setiap perkara yang telah masuk dalam ranah pengadilan, dalam bidang perdata dan tata usaha negara disisni jaksa apabila mendapat kuasa khusus dari pihak-pihak terkait baru bisa melaksanakan tugas yang telah dipercayai dengan diberi kuasa khusus untuk menyelesaikan perkara-perkara di bidang perdata dan tata usaha negara. Dan tidak semua jaksa bisa mendapat kuasa khusus, melainkan jaksa yang bertugas dalam bidang perdata dan tata usaha negara saja.

Kejaksaan yang mendapat kuasa khusus dapat memberi bantuan hukum, pertimbangan, pelayanan hukum yang dapat mewakili pemerintah maupun negara untuk di dalam maupun di luar pengadilan sebagai usaha menyelamatkan kekayaan negara, menjamin kepastian hukum dan menjaga kewibawaan pemerintah, dan upaya menyelamatkan dan memulihkan kekayaan negara dapat dilakukan dengan melakukan gugatan perdata dan pembayaran uang pengganti.

Kegiatan jaksa dalam melaksanakan tugasnya di bidang perdata dan tata usaha negara diantaranya kegiatan yang mewakili instansi pemerintah atau Badan Usaha Milik Negara/Daerah dalam menghadapi sengketa perdata dan tata usaha negara. Pelaksanaan bantuan hukum dalam sengketa tersebut dapat dilakukan baik melalui pengadilan (Litigasi) maupun di luar pengadilan (non litigasi). Untuk menyelesaikan perkara dibidang perdata dan tata usaha negara tidak harus melalui pengadilan, melainkan dapat diselesaikan melalui proses negoisasi, mediasi, fasilitasi atau arbitrase yang kesemuanya mencakup penyelsaian di luar pengadilan. ${ }^{6}$ Mengenai tugas dan

${ }^{6}$ Suryadi Agus et al, Optimalisasi Peran Datun Kejaksaan dalam Penegakan Hukum, (Jakarta: Pusat Penelitian dan Pengembangan Kejaksaan RI, 2004).

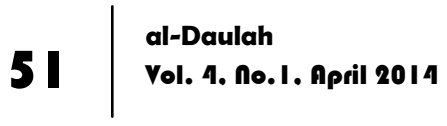


wewenang jaksa dalam bidang perdata dan tata usaha negara, yang akan dibahas dalam penelitian disini adalah mengenai wewenang dan tugas jaksa dalam memulihkan kekayaan negara.

Istilah kekayaan negara, sudah tidak asing lagi untuk didengar. Ada beberapa istilah dalam penyebutan kekayaan negara, seperti aset negara dan barang milik negara. Menurut Titik Triwulan Tutik, dalam kalimat kekayaan negara terdapat dua aspek, yakni negara dan kekayaan. Dalam bab I RUU kekayaan negara dapat diartikan sebagai benda berwujud dan tak berwujud, baik bergerak maupun tak bergerak yang mempunyai nilai, yang dimiliki atau dikuasai oleh negara. ${ }^{7}$

Penggolongan barang milik negara atau kekayaan negara diantaranya barang-barang bergerak dan barang tidak bergerak. Sedangkan pengertian kekayaan negara menurut UU Perbendaharaan pasal 1 adalah "semua barang yang dibeli atau diperoleh atas Anggaran Pendapatan dan Belanja Negara/Daerah atau yang berasal dari perolehan lain yang sah". ${ }^{8}$ Pengertian dari UU perbendaharaan tersebut hampir sama dengan yang dijelaskan dalam Peraturan Pemerintah No 6 tahun 2006 pasal 1 tentang Pengelolaan Barang Milik Negara atau daerah, meliputi: "Barang yang dibeli atau diperoleh atas beban Anggaran Pendapatan Belanja Negara/Daerah atau berasal dari perolehan lain yang sah".

Kekayaan negara merupakan bagian yang tidak terpisahkan dari keuangan negara, pemahaman terhadap pengelolaan keuangan negara berarti juga pemehaman terhadap pengelolaan kekayaan negara. Dengan mengetahui tentang uraian pengelolaan barang, proses pengadaan barang untuk keperluan negara serta proses pemeriksaan dan pengawasannya akan menambah

7 Titik Triwulan Tutik, Hukum Tata Usaha Negara dan Hukum Acara Peradilan Tata Usaha Negara Indonesia, (Jakarta: Kencana Prenada Media Group, 201 I), 368.

${ }^{8}$ Lembaran Negara No.5 Tahun 2004 ( 14 januari 2004) tentang UU Perbendaharaan Negara No I tahun 2004. 
pengetahuan tentang mekanisme pengelolaan harta kekayaan negara. ${ }^{9}$

UU tentang keuangan negara juga dijelaskan mengenai kekayaan negara, yakni pada pasal 1 huruf g, bahwa: "kekayaan negara/kekayaan daerah yang dikelola sendiri atau oleh pihak lain berupa uang, surat berharga, piutang, barang, serta hak-hak lain yang dapat dinilai dengan uang, termasuk kekayaan yang dipisahkan pada perusahaan negara/ perusahaan daerah". ${ }^{10}$ Jadi pengertian kekayaan negara adalah barang milik negara baik berupa uang ataupun barang serta yang dikuasai atau yang dimilki oleh oleh negara. Untuk lebih memahami tentang konsep kekayaan negara, maka disini akan dijelaskan mengenai keuangan negara yang mempunyai hubungan yang tidak dapat dipisahkan dengan kekayaan negara. secara nyata telah dijelaskan dalam UU keuangan negara mengenai definisi dari keuangan itu sendiri, yang teertera pada pasal 1 ayat 1, yakni: "Keuangan negara adalah semua hak dan kewajiban negara yang dapat dinilai dengan uang, serta segala sesuatu baik berupa uang maupun berupa barang yang dapat dijadikan milik negara berhubung dengan pelaksanaan hak dan kewajiban tersebut". ${ }^{11}$

\section{Kewenangan Jaksa dalam Memulihkan Kekayaan Negara}

Ditinjau dari ruang lingkupnya, kekayaan negara dapat diartikan keseluruhan harta negara baik yang dimiliki maupun yang dikuasai, kekayaan yang dipisahkan dan yang tidak dipisahkan, yang bertujuan untuk kesejahteraan rakyat. Terdapat dua aspek kekayaan negara, yakni: barang yang dimiliki negara (domain privat), dan barang yang dikuasai negara (domain publik). ${ }^{12}$

${ }^{9}$ Gunawan Widjaja, Pengelolaan Harta Kekayaan Negara, Suatu Tinjauan Yuridis, (Jakarta: PT Raja Grafindo Persada, 2002), 19.

${ }^{10}$ Lembaran Negara Republik Indonesia (28 April 2003) tentang UU Keuangan Negara No 17 tahun 2003.

11 lbid.

12 Titik Triwulan Tutik, Hukum Tata Usaha Negara, 369. 
Kekayaan yang dimiliki negara mengacu pada Undang-Undang Dasar Republik Indonesia 1945 pasal 23.

Kekayaan yang dimiliki oleh negara mencakup kekayaan negara yang dipisahkan dan kekayaan negara yang tidak dipisahkan. Kekayaan negara yang dipisahkan adalah kekayaan negara yang berasal dari APBN atau perolehan lainnya yang sah yang dijadikan penyertaan modal negara pada BUMN. Sedangkan kekayaan negara yang tidak dipisahkan adalah kekayaan negara yang ada pada departemen/lembaga atau Badan Hukum Pemerintah yang berasal dari Anggaran Pendapatan dan Belanja Negara (APBN) atau perolehan lainnya yang sah. Perolehan lainnya yang sah dapat berupa kekayaan dari putusan pengadilan, hibah, perjanjian kontrak, ataupun diatur berdasarkan undangundang. ${ }^{13}$

Kekayaan yang dikuasai negara adalah yang melekat pada kewenangan negara untuk mengelola dan menggunakan kekayaan tersebut sebesar-besarnya atas kemakmuran masyarakat. ${ }^{14}$ Domain Publik disini mengacu pada UUD 1945 Pasal 33 ayat 3, yaitu: "Bumi dan air dan kekayaan alam yang terkandung di dalamnya dikuasai oleh Negara dan dipergunakan untuk sebesar-besarnya kemakmuran rakyat". Atas ketentuan pasal 33 UUD 1945 tersebut, UU Pokok Agraria menetapkan dalam pasal 2 ayat 2 dan 3 bahwa: ${ }^{15}$

Permasalahan yang terjadi dalam pengelolaan kekayaan negara menurut tim pengelola aset pada kementrian dalam negeri: ${ }^{16}$ Kurangnya tingkat ketelitian pada nilai kekayaan yang dikelola, kurang optimalnya penggunaan barang milik negara dalam rangka mendukung tugas pokok dan fungsi pemerintah, kurang optimalnya pemanfaatan dan pemindahtanganan Barang

\footnotetext{
13 Ibid.

${ }^{14}$ Ibid., 370.

15 Lembaran Negara Republik Indonesia, No.104 tahun 1960 (24 september 1960) UU RI tentang Peraturan Dasar Pokok-Pokok Agraria, No. 5 Tahun 1960.

${ }^{16}$ Dhani Nasution, dalam http://dedoubleyou.wordpress.com/20 I3/02/I5/strategi-pengelolaanbarang-milik-negaradaerah-iii/, diakses I 5 Februari 2013.
} 
Milik Negara dalam upaya menghasilkan pendapatan negara, meminimalisasi terjadinya kerugian negara sebagai akibat dari pengelolaan Barang Milik Negara.

Semua jenis kekayaan negara baik yang dimiliki ataupun yang dikuasai sudah ditentukan dalam masing-masing hukum, apabila hukum tersebut telah dilaksanakan dengan baik, maka tinggal membenahi sumber daya manusianya untuk menjalankan semuanya. Terlaksanya pengelolaan kekayaan negara dengan baik tidak luput dari peran serta pemerintah dalam mengawasi dan menegakkan hukum, serta peran masyarakat tidak kalah penting demi terlaksananya pengelolaan kekayaan negara dengan baik, terutama peran tersebut dalam pengawasan pengelolaan, sehingga tidak terjadi hal-hal yang tidak diinginkan seperti kerugian pada kekayaan negara.

Berbicara mengenai upaya dalam memulihkan kekayaan negara, tidak terlepas dari adanya kerugian yang terjadi pada kekayaan negara, baik kekayaan negara yang dipisahkan atau kekayaan negara yang tidak dipisahkan. Pengertian kerugian negara disebutkan dalam UU Perbendaharaan Negara pasal 1 ayat 22: "Kerugian Negara/Daerah adalah kekurangan uang, surat berharga, dan barang, yang nyata dan pasti jumlahnya sebagai akibat perbuatan melawan hukum baik sengaja maupun lalai". Bentuk material kerugian berupa uang, surat berharga, barang. Subyek hukum dalam kerugian keuangan negara adalah yang berkaitan dengn negara dan daerah, serta kekayaan di dalamnya dan modal yang sebagian besar merupakan milik negara, subyek hukum disini seperti perseroan, BUMN/D yang mempunyai kaitan sangat erat dengan kekayaan negara.

Adapun jenis kerugian negara dapat terjadi dalam proses pengelolaan kekayaan negara, yang berkenaan dengan penerimaan, pengeluaran, aset dan kewajiban. Kerugian negara menurut Theodorus $\mathrm{m}$. Tanukotta diaplikasikan dengan pohon kerugian negara, dimana pohon tersebut meiliki cabang, dan dalam cabang saling menunjukkan kaitannya antara perbuatan

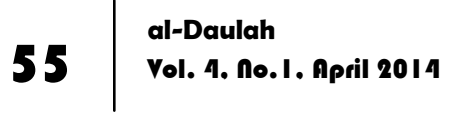


melawan hukum dengan laporan keuangan pemerintah pusat maupun daerah atau laporan keuangan BUMN/D.

Ukuran dalam kerugian negara tidak dapat ditetapkan dengan ditaksir atau dengan perkiraan, karena dalam menentukan besarnya kerugian negara harus dengan nyata dan pasti. Adapun pejabat yang bertugas dalam memeriksa keuangan negara seperti yang disebutkan dalam UUD 1945, yakni Badan Pemeriksa Keuangan, tugas dari BPK tersebut adalah: "Memeriksa pengelolaan dan tanggung jawab keuangan negara yang dilakukan oleh Pemerintah Pusat, Pemerintah Daerah, Lembaga Negara lainnya, Bank Indonesia, Badan Usaha Milik Negara, Badan Layanan Umum, Badan Usaha Milik Daerah, dan lembaga atau badan lain yang mengelola keuangan negara". ${ }^{17}$

UU BPK diatur untuk menjadi pedoman dalam melakukan pemeriksaan (audit), selain mengikat pada pemeriksa dan mengikat bagi terperiksa. Jaksa dalam menjalankan tugasnya, tidak terlepas dari peran untuk bekerja sama dengan lembaga yang benar-benar berwenang dalam hal keuangan negara, karena jaksa tidak mempunyai wewenang dalam menghitung apabila terjadi kerugian keuangan negara. Maka jaksa dapat menerima hasil perhitungan kerugian keuangan negara dari badan pemeriksa keuangan negara atau lembaga audit lainnya terkait dengan kasus yang ditangani oleh jaksa.

Jaksa Agung Muda bidang Perdata dan Tata Usaha Negara yang bertugas dalam bidang perdata dan tata usaha negara dibentuk untuk turut serta dalam memulihkan kekayaan negara. Dalam memulihkan kekayaan negara, diperlukan upaya untuk penyelesaiannya dengan cara di dalam maupun di luar pengadilan, seperti yang telah dijelaskan dalam tugas jaksa dalam UU kejaksaan pasal 30 ayat 2. Berdasarkan uraian tersebut, setidaknya ada tiga proses penyelesaian yang bisa dilakukan jaksa

${ }_{17}$ Undang-undang Dasar Republik Indonesia Tahun 1945.

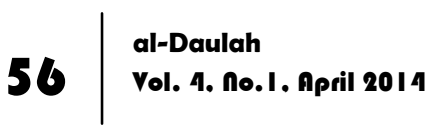


dalam memulihkan kekayaan negara, yakni proses melalui hukum administrasi, hukum pidana dan terakhir melalui hukum perdata.

Adanya hubungan sebab akibat dalam melawan hukum dan kerugian negara yang ditimbulkan, dimaksudkan untuk memberi penegasan siapa yang seharusnya dapat mempertanggungjawabkan perbuatannya. Hubungan sebab akibat merupakan salah satu teori dalam hukum perdata tentang perbuatan melawan hukum yang diadopsi dari hukum administrasi, yakni pada pasal 1365 KUHPerdata: "tiap perbuatan melanggar hukum, yang membawa kerugian kepada orang lain, mewajibkan orang yang karena kesalahannya menerbitkan kerugian itu, mengganti kerugian tersebut". ${ }^{18}$

Hubungan kausalitas tidak hanya dibutuhkan dalam bidang hukum pidana saja, melainkan dalam hukum perdata hubungan kausalitas sangat penting. Hubungan kausalitas dalam hukum pidana adalah untuk menentukan siapa yang dapat mempertanggungjawabkan terhadap timbulnya suatu akibat, sedangkan dalam hukum perdata adalah untuk meneliti adakah hubungan kausal antara perbuatan melawan hukum dan kerugian yang ditimbulkan, sehingga pelaku dapat dipertanggungjawabkan. ${ }^{19}$

Upaya pemulihan kekayaan negara yang dilakukan melalui instrumen perdata sepenuhnya tunduk pada disiplin hukum perdata materiil maupun formil, meskipun berkaitan dengan tindak pidana korupsi. Pelaksanaan penanganan perkara melalui proses perdata tidak mengenyampingkan proses hukum pidana, misalnya dalam kasus kerugian negara akibat korupsi, kasus tersebut telah melalui proses peradilan pidana, akan tetapi dalam gugatan ganti kerugian bisa dibuktikan melalui proses peradilan perdata. Namun perkara tersebut, tidak akan bisa dilakukan dalam peradilan perdata jika penyidik dari peradilan pidana

\footnotetext{
${ }^{18}$ Kitab Undang-undang Hukum Acara Perdata.

${ }^{19}$ Abdul Halim dan Icuk Rangga Bawono, Pengelolaan Keuangan Negara-Daerah, (Yogyakarta: UPP STIM YKPN, 20I I), 26.
} 
belum memberikan pelimpahan perkara untuk dilanjutkan dalam peradilan perdata.

Sistem pembuktian dalam perkara perdata yang digunakan adalah pembuktian formil, beban pembuktian tersebut ada pada jaksa atau pihak atau instansi yang dirugikan sebagai penggugat, kewajiban penggugat dalam pembuktian tersebut adalah: ${ }^{20}$ Bahwa secara nyata telah terjadi kerugian negara, Kerugian negara sebagai akibat yang berkaitan dengan perbuatan tersangka, terdakwa atau terpidana yang dapat digunakan dalam pemulihan kekayaan Negara, Adanya benda milik tersangka, terdakwa atau terpidana yang dapat diguanakan untuk pengembalian kerugian negara.

Upaya lain yang dilakukan jaksa untuk memulihkan kekayaan negara, dengan menggunanakan fungsi yang telah dijelaskan dalam UU, yakni sebagai penegak hukum, bantuan hukum dan pelayanan hukum. Dalam kedudukannya, kejaksaan dapat mengajukan gugatan dan permohonan dalam bidang perdata, tindakan dalam mengajukan tuntutan atau gugatan perdata adalah: tuntutan atau gugatan ganti rugi penyetoran kembali, tuntuan atau gugatan perbendaharaan, tuntutan atau gugatan perdata berupa pengenaan denda, beserta ganti rugi dan lain-lain. Lingkup kegiatan yang dilakukan jaksa dalam memulihkan kekayaan negara, yakni melalui dua proses: di dalam pengadilan (ligitasi) dan di luar pengadilan (non litigasi). ${ }^{21}$

Kegiatan jaksa dalam pelaksanaan tugas dan wewenangnya di bidang perdata, yang salah satunya adalah pemulihan kekayaan negara untuk dan atas nama pemerintah atau negara. Dengan pedoman bahwa upaya litigasi merupakan upaya terakhir dalam menyelesaikan perkara, karena penyelesaian dengan jalan damai di luar pengadilan merupakan upaya pertama sebelum dilanjutkan ke pengadilan. Upaya yang dilakukan jaksa dengan

\footnotetext{
${ }^{20} \mathrm{lbid}, 29$.

${ }^{21}$ Ely Kusumastuti, "Fungsionalisasi Kewenangan Kejaksaan dalam Bidang Perdata", Thesis, (Semarang: Universitas Diponogoro, 2002).
} 
cara penyelesaian di dalam pengadilan yakni dengan mengajukan gugatan perdata untuk mendapatkan kembali kekayaan negara, dengan kuasa khusus yang telah diamanahkan kepada kejaksaan.

Kejaksaan sebagai kuasa dari instansi pemerintah atau negara dapat juga melakukan penyelesaian sengketa di luar pengadilan. Kegiatan tersebut meliputi pemberian pertimbangan hukum, nasehat dan opini hukum. Upaya jaksa tersebut dilakukan melalui negoisasi, mediasi, arbitrase. Proses dengan cara damai di luar pengadilan banyak dipilih oleh masyarakat, karena dianggap lebih mudah dan tidak membutuhkan waktu lama, dibandingkan berproses melalui pengadilan.

\section{Peran Wilayah al-Hisbah dalam Menyelesaikan Sengketa}

Ulama fikih siyasah mendefinisikan hisbah sebagai lembaga peradilan yang menangani kasus pelanggaran secara nyata terhadap perintah berbuat baik dan larangan berbuat munkar. ${ }^{22}$ Sedangkan lembaga hisbah adalah badan resmi negara yang diberi kewenangan untuk menyelesaikan masalah-masalah ataupun pelanggaran ringan. Dengan demikian tugas utama lembaga tersebut adalah mengajak umat berbuat baik dan mencegah perbuatan munkar. Wilayah al-hisbah sebagaimana firman Allah dalam surah Ali Imran ayat 104 sebagai berikut:

Dan hendaklah ada di antara kamu segolongan umat yang menyeru kepada kebajikan, menyuruh kepada yang ma'ruf dan mencegah dari yang munkar, merekalah orang-orang yang beruntung. ${ }^{23}$

Pada dasarnya hisbah merupakan tugas setiap pribadi muslim, sesuai dengan ayat al-Qur'an di atas, kemudian didukung sabda Nabi SAW: ${ }^{24}$

Dari Abi Said al-khudri r.a berkata: saya mendengar Rasulullah $S A W$ bersabda: barang siapa diantara kamu yang melihat

\footnotetext{
${ }^{22}$ Azyumardi Azra, Ensiklopedi Islam Jilid 3, (Jakarta: PT Ichtiar Baru Van Hoeve, 2005), 33.

${ }^{23}$ Departemen Agama RI, Al-Qur'an dan Terjemahannya, (Bandung: Syaamil Al-Qur'an, 2007), 63.

${ }^{24}$ Al-Imam Abu Zakariya bin Syarifuddin an-Nawawi, Riyadussalihin, (Al-Haramain, 2005), 102.
}

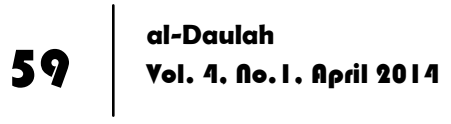


kemungkaran, hendaklah berusaha mengubahnya dengan tangannya, apabila tidak mampu merubah dengan tangan hendaklah mengubah dengan lisannya dan apabila dengan lisanpun tidak mampu maka hendaklah mengubah dengan hatinya. (HR. Muslim). ${ }^{25}$

Perintah diatas meliputi berbagai macam permasalahan, diantaranya kewajiban pelaksanaan undang-undang, bertanggung jawab terhadap segala perbuatan yang dilakukan, dan menyeru untuk berbuat kebaikan dan melarang hal-hal yang tidak mendatangkan maslahat bagi ummat serta melarang perbuatan yang mungkar. Agar dapat membawa perjalanan negara pada arah yang baik.

Wilayah al-hisbah telah dikenal dan berlangsung sejak zaman Rasulullah SAW, yang dalam kesehariannya, beliau tidak pernah lepas dari menyeru kegiatan amar ma'ruf nahi mungkar. Adapun tugas Wilayah al-hisbah adalah memberi bantuan kepada orangorang yang tidak dapat mengembalikan hak-haknya tanpa bantuan petugas-petugas hisbah. Ibnu Khaldun mengungkapkan secara rinci bahwa hisbah adalah institusi urusan keagamaan, kewajiban bagi orang yang mengurusi persoalan kaum muslimin yang dipandang mempunyai keahlian. ${ }^{26}$ Pejabat dalam Wilayah alhisbah disebut dengan al-muhtasib, yang bertugas mengatur ketertiban umum, mencegah terjadiya pelanggaran hak-hak tetangga, mengawasi berlaku tidaknya undang-undang di masyarakat, dan terkadang muhtasib ini memberikan putusan dalam perkara-perkara yang perlu segera diselesaikan. ${ }^{27}$

Tugas seorang muhtasib tidak hanya menyelesaikan suatu sengketa dan mendengar pengaduan saja, namun juga berhak memberi putusan yang termasuk pada bidangnya. Hal ini dilakukan, apabila ada suatu sengketa yang harus segera

${ }^{25}$ Departemen Agama, Ensiklopedi Islam di Indonesia, (Jakarta: CV Anda Utama, 1993), 117.

${ }^{26}$ Oyo Sunaryo Mukhlas, Perkembangan Peradilan Islam dari Kahin di Jazirah Arab ke Peradilan Agama di Indonesia, (Bogor: Ghalia Indonesia, 20I I), 24.

${ }^{27}$ Jaelani Aripin, Peradilan Agama dalam Bingkai Reformasi Hukum di Indonesia, (Jakarta: Kencana Prenada Media Group, 2008), 168. 
diselesaikan agar tidak menimbulkan dampak yang lebih buruk, jika sengketa tersebut melalui proses pengadilan akan memakan waktu yang lebih lama. Akan tetapi muhtasib tidak berhak mendengarkan keterangan saksi dalam memutuskan suatu hukum dan tidak berhak menyuruh bersumpah terhadap orang yang menolak gugatan, karena hal tersebut adalah wewenang hakim pengadilan. ${ }^{28}$

Muhtasib juga dapat melakukan yang bukan wewenang para penyelenggara negara dan para hakim, serta anggota dewan lainnya, namun muhtasib dapat melakukan penuntutan terhadap perkara yang menyimpang yang diketahuinya kepada lembaga peradilan. Beberapa langkah yang dapat dilakukan oleh almuhtasib, dapat berupa saran seperlunya, teguran, kecaman, pelurusan dengan paksa, ancaman penjara, dan pengusiran dari kota. Al-muhtasib diharuskan untuk memilih sanksi terberat hanya apabila sanksi yang lebih ringan tampaknya tidak berpengaruh terhadap orang yang dihukum. ${ }^{29}$

Kewenangan Wilayah al-hisbah ini tertuju kepada tiga hal: pertama, dakwaan terkait dengan kecurangan dan pengurangan takaran atau timbangan, kedua: dakwaan terkait dengan penipuan dalam komoditi dan harga seperti pengurangan takaran dan timbangan di pasar, menjual bahan makanan yang sudah kadaluarsa dan ketiga: dakwaan terkait dengan penundaan pembayaran hutang padahal pihak yang berhutang mampu membayarnya hutangnya. Wilayah al-hisbah yang ditetapkan oleh hukum Islam secara garis besar menyerupai lembaga kejaksaan, sedangkan muhtasib dapat disamakan dengan jaksa, karena mereka adalah orang-orang yang bertugas memelihara hak-hak umum serta tata tertib masyarakat. ${ }^{30}$

\footnotetext{
${ }^{28}$ A. Basiq Djali,, Peradilan Islam, (Jakarta: Amzah, 2012), 129.

${ }^{29}$ Ibnu Taimiyah, Tugas Negara Menurut Islam, (Yogyakarta: Pustaka Pelajar, 2004), 14.

30 Teungku Muhamad Hasbi Ash Shiddieqy, Peradilan dan Hukum Acara Islam, (Semarang: PT Pustaka Rizki Putra, 1997), 101.
} 
Dari tugas dan wewenang wilayah al-hisbah yang telah dijelaskan diatas, jelas bahwa wilayah al-hisbah berperan penting dalam menyelesaikan sengketa, diantaranya apabila terjadi penyimpangan terhadap pendapatan negara dalam pengelolaannnya, yang mana dari penyimpangan tersebut dapat merugikan pendapatan negara dan berimbas pada masyarakat. Tugas hisbah di sini adalah mengantisipasi dan mencegah adanya penyimpangan tersebut. Penyelesaian sengketa-sengketa yang ditangani wilayah al-hisbah tidak lain dengan yang menjadi kewajiban wilayah al-hisbah apabila melihat kemungkaran yang terjadi dalam masyarakat.

Seperti yang telah dijelaskan dalam tugas dan wewenang wilayah al-hisbah, langkah-langkah yang dapat dilakukan yakni dengan seperlunya, teguran dan kecaman. Kegiatan yang dilakukan wilayah al-hisbah dalam menyelesaikan sengketa, yaitu diselesaikan diluar ranah peradilan, yang mana dapat diselesaikan dengan cara perdamaian diantara pihak-pihak yang bersengketa. Tugas hisbah menjadi wasit diantara orang-orang yang bersengketa. Tradisi penyelesaian sengketa atau konflik melalui upaya perdamaian telah dikembangkan Islam sejak lama, bahkan sebelum Muhammad mengemban tugas kerasulannya.

Pada era pemerintahan al-Khulafa al-Rasyidun, terutama ketika Umar bin Khattab menjadi khalifah, tradisi perwasitan dalam penyelesaian sengketa ini semakin dibudayakan dalam praktek kehidupan bermasyarakat, sehingga tidak hanya diterapkan terhadap masalah-masalah yang berkaitan dengan hukum keluarga dan perniagaan saja, tetapi juga dalam pertikaian di bidang sosial dan politik. ${ }^{31}$

Sama halnya dengan negara Indonesia pada saat ini, dalam kenegaraan dan pemerintahannya, dalam berbagai produk hukum positif dan hukum adat yang berlaku senantiasa mengedepankan

\footnotetext{
${ }^{31}$ Ramdlon Naning, "Penyelesaian Sengketa Dalam Islam, Peran Badan Arbitrase Syariah Nasional dan Kewenangan Pengadilan Agama Dalam Menyelesaikan Sengketa Ekonomi Syariah", Artikel, 06 September 2008.
} 
prinsip perdamaian, musyawarah mufakat untuk menyelesaikan sengketa atau konflik, apabila upaya ini sudah ditempuh namun tidak membuahkan hasil yang memuaskan semua pihak yang bertikai, maka alternatif akhirnya adalah dengan menempuh penyelesaian melalui jalur hukum.

\section{Keuangan Negara dalam Islam}

Bait al-mal adalah suatu lembaga yang mempunyai tugas khusus menangani segala harta umat, baik berupa pendapatan maupun pengeluaran negara. Jadi bait al-mal merupakan pos yang diperuntukkan untuk semua pendapatan dan pengeluaran harta yang menjadi hak kaum muslimin. Setiap hak yang wajib dibagikan kepada setiap kaum muslimin berlaku dalam bait almal. ${ }^{32}$

Mengenai sumber pendapatan yang tetap dalam bait al-mal yakni terdiri dari fai', ganimah, kharaj, jizyah dan pendapatan dari hak milik umum lainnya. Sedangkan pemasukan dari hak negara diantaranya 'usyr, khumus, dan zakat. Harta yang sudah masuk dalam lembaga tersebut hanya dibelanjakan untuk keperluan umat, negara dan yang telah menjadi kebijakan negara. Adapun apabila harta tersebut cukup untuk keperluan umat, maka cukup memakai harta tersebut, namun apabila tidak cukup, maka negara mewajibkan pajak (daribah) kepada seluruh umat untuk melaksanakan tuntutan pelayanan umat. ${ }^{33}$ Pendapatan negara pada saat ini yang menyerupai pada masa khilafah adalah seperti zakat, jizyah, kharaj, dan 'usyr.

Prinsip utama dari pengeluaran negara adalah untuk mewujudkan kesejahteraan masyarakat dan kepentingan negara sendiri. Karena tercapainya kesejahteraan masyarakat merupakan

\footnotetext{
32 Taqyuddin An-Nabhani, An-Nidlam Al-lqtisadi Fi al-Islam, diterjemahkan oleh Moh. Maghfur Wachid, Membangun Sistem Ekonomi Alternatif Perspektif Islam, (Surabaya: Risalah Gusti, 1996), 253.

33 Ibid., 254.
} 
langkah awal tercapainya kesejahteraan negara Islam. Adapun pengeluaran negara dapat ditetapkan berdasarkan enam aspek: ${ }^{34}$

1. Bait al-mal sebagai kas negara yang berhak terhadap terjadinya kekurangan dan untuk pelaksaan jihad.

2. Harta yang menjadi kas tersendiri dalam bait al-mal seperti zakat merupakan hak mustahiq.

3. Apabila ada harta yang menjadi hak seseorang yang telah memberikan jasa, kemudian mereka meminta harta tersebut sebagai upah atas jasanya.

4. Dan bait al-mal sebagai pihak yang berwenang dalam pengeluaran untuk kemaslahatan dan kemanfaatan rakyat.

5. Pengeluaran dilakukan untuk kemaslahatan dan kemanfaatan, bukan sebagai kompensasi.

6. Pengeluaran diadakan secara emergency, karena adanya musibah yang menimpa rakyat.

Dana yang terhimpun dalam bait al-mal harus digunakan untuk kepentingan masyarakat, sehingga pengelolaan kekayaan negara yang sudah terhimpun harus dibagi dengan adil, dan tidak diperbolehkan untuk mengeluarkan uang negara atas kehendaknya sendiri. Menurut Muhammad Iqbal, mengenai pengeluaran negara sebagaimana yang dijalankan dalam pemerintahan Islam harus mempertimbangkan kebutuhan negara dan warganya, yakni: ${ }^{35}$ untuk fakir dan miskin, untuk meningkatkan profesionalisme tentara dalam rangka pertahanan dan keamanan negara, untuk menegakkan supremasi hukum, untuk membiayai sektor pendidikan dalam rangka menciptakan sumber daya manusia yang bertakwa dan berilmu pengetahuan yang luas, untuk membayar gaji pegawai dan pejabat negara, untuk pengembangan infrastruktur dan sarana/prasarana fisik, untuk mewujudkan kesejahteraan umum dan pemerataan pendapatan serta kekayaan.

34 Ibid, 264-266.

35 Muhammad Iqbal, Fiqh Siyasah Kontekstualisasi Doktrin Politik Islam, (Jakarta: Gaya Media Pratama, 200I), 288. 
Pengelolaan kekayaan negara yang terkumpul dalam bait almal sebenarnya tidak terbatas pada unsur-unsur yang disebutkan diatas, mengingat pengeluaran dan belanja negara tidak terlepas dari sumber pendapatan negara berasal dan pengelolaan kekayaan negara tersebut harus diprioritaskan untuk mewujudkan kesejahteraan masyarakat dan negara. Dan tata cara pendisrtibusian kekayaan negara yang wajib didahulukan adalah yang menempati tingkat prioritas utama. Tentunya prioritas paling utama adalah untuk kemaslahatan kaum muslimin secara umum, yakni dengan cara memberikan sesuatu yang bermanfaat bagi kaum muslimin.

\section{Kewenangan Jaksa dalam Memulihkan Kekayaan Negara Menurut Fikih Siyasah}

Pandangan dalam kajian fikih siyasah mengenai kewenangan jaksa dalam memulihkan kekayaan negara, memang tidak dijumpai mengenai pemulihan kekayaan negara akibat dari kerugian negara oleh wilayah hisbah. Akan tetapi wilayah hisbah yang mempunyai tugas dalam melaksanakan amar ma'ruf nahi munkar, pelaksana undang-undang dan mempunyai tugas dalam melakukan pengawasan terhadap pejabat negara yang melakukan penyimpangan.

Dari tugas dalam pengawasan terhadap prilaku pejabat negara dapat saja terjadi penyimpangan salah satunya dalam hal kekayaan negara yang dapat merugikan keuangan negara, karena pengelolaan kekayaan negara adalah tugas-tugas dari pada pejabat negara. Apabila pejabat yang berwenang menangani penarikan zakat, sedekah maupun infaq dari kaum muslimin dalam praktek pemungutannya menyalahi aturan yang sebenarnya, maka wilayah hisbah berhak menarik kembali harta yang bukan menjadi haknya, semisal hadiah-hadiah yang diberikan karena sebuah aktifitas.

Disebutkan dalam Sahih Bukhari Muslim dari Abi Humaid As-Saidy r.a yang mengatakan bahwa Rasulullah SAW telah

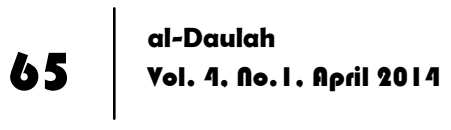


mengangkat seorang pejabat dari Azdi (sebuah wilayah di Islam) bernama Ibnu Lutbiyyah untuk mengurus sedekah, maka Rasulullah bersabda: ${ }^{36}$

"Bagaimana keadaan seseorang yang kami angkat untuk sebuah amal yang Allah percayakannya kepada kita. Kemudian (dia) berkata, "ini untukmu dan ini aku hadiahkan kepada diriku", maka marilah duduk-duduk (berkunjung) di rumah ayah atau ibunya, sebernya kita lihat benarkah diahdiahkan kepadanya atau tidak (berhakkah ia mengambil harta itu atau tidak?). Demi Dzat dan jiwaku berada dalam genggaman-Nya, dia tidak berhak mengambil sesuatu, kecuali pada hari kiamat nanti akan menjadi beban dipundaknya. Jika yang diambil itu berupa onta, maka onta itu akan melenguh, jika yang diambil itu sapi, maka sapi itu akan melenguh, jika berupa kambing, maka ia akan mengembik (di hadapan tuannya tanda protes)." Kemudian Rasulullah saw. mengangkat kedua tangannya sampai kami melihat kedua ketiak beliau yang berwarna putih, seraya berdo'a "Ya Allah, bukankah aku telah menyampaikannya?" Rasulullah mengucapkan itu tiga kali". (HR. Syaikhani)

Dari tugas wilayah hisbah dalam menyelesaikan sengketa, maka wilayah hisbah berhak mengajukan tuntutan karena terjadinya penyimpangan tersebut untuk memperoleh kembali hak dengan terjadinya penyimpangan. Jadi dapat dibenarkan mengenai tugas jaksa penuntut umum dalam memulihkan kekayaan negara, salah satunya dengan mengajukan tuntutan atau gugatan agar kekayaan negara dapat dipulihkan kembali dengan tugas wilayah hisbah dalam melakukan tuntutan sebagai penuntut umum dalam peradilan Islam.

Salah satu tugas wilayah hisbah adalah menyelesaikan sengketa di luar peradilan, tugas tersebut dapat berupa memutuskan perkara dalam sengketa yang harus segera diselesaikan dan menyelesaikan sengketa secara damai dengan menjadi wasit sebagai penengah. Dengan cara memangggil para 
pihak untuk meluruskan suatu sengketa dan untuk memperoleh keputusan yang dapat disepakati bersama. Maka tugas jaksa penuntut umum yang dapat menyelesaikan sengketa di luar pengadilan dengan cara damai, sama halnya dengan tugas wilayah hisbah dalam menyelesaikan sengketa di luar peradilan dengan jalan damai.

Penyelesaian sengketa secara damai di luar pengadilan dalam peradilan di Indonesia saat ini ternyata telah dikembangkan Islam sejak lama, bahkan sebelum Nabi Muhammad mengemban tugas ke Rasulannya, dengan menjadi wasit dari pihak-pihak yang bersengketa, serta telah penyelesaian sengketa dengan cara damai telah dijelaskan dalam firman Allah surat Al-Hujurat ayat 9:

"Dan kalau ada dua golongan dari mereka yang beriman itu berperang hendaklah kamu damaikan antara keduanya! tapi kalau yang satu melanggar perjanjian terhadap yang lain, hendaklah yang melanggar perjanjian itu kamu perangi sampai surut kembali pada perintah Allah. Kalau dia telah surut, damaikanlah antara keduanya menurut keadilan, dan hendaklah kamu berlaku adil; Sesungguhnya Allah mencintai orang-orang yang berlaku adil. ${ }^{37}$

Berdasarkan hal tersebut, dapat diketahui bahwa kewenangan jaksa dalam memulihkan kekayaan negara menurut fikih siyasah adalah kewenangan jaksa penuntut umum dengan pendekatan fikih siyasah yang berkesesuaian dengan lembaga hisbah dalam melaksanakan tugasnya menyelesaikan sengketa, sebagai penuntut umum dan sebagai pengawas pejabat pemerintah apabila terjadi penyimpangan dalam kepemerintahannya. Dari tugas tersebut dapat dibenarkan Upaya jaksa dalam menyelesaikan sengketa dengan jalan litigasi dan non litigasi, sama halnya dengan lembaga hisbah dalam melakukan penuntutan dan pemanggilan para pihak untuk diselesaikan secara damai.

${ }^{37}$ Departemen Agama RI, A/-Qur'an dan Terjemahannya, 316.

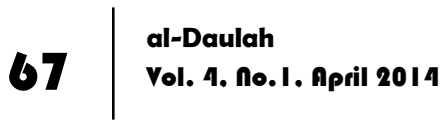




\section{Penutup}

Kewenangan jaksa dalam memulihkan kekayaan negara menurut Undang-Undang Kejaksaan No 16. Tahun 2004, adalah kewenangan dengan mendapat kuasa khusus dari instansi pemerintah atau negara, baik di dalam maupun di luar pengadilan sebagaimana dijelaskan dalam pasal 30 ayat 2 undang-undang kejaksaan. Dalam memulihkan kekayaan negara akibat yang ditimbulkan dari kerugian negara. Upaya memulihkan kekayaan tersebut dilakukan dengan cara mengajukan gugatan di dalam pengadilan atau dengan cara perdamaian di luar pengadilan.

Kewenangan jaksa dalam memulihkan kekayaan negara menurut fikih siyasah adalah kewenangan jaksa penuntut umum dengan pendekatan fikih siyasah yang berkesesuaian dengan lembaga hisbah dalam melaksanakan tugasnya menyelesaikan sengketa, sebagai penuntut umum dan sebagai pengawas pejabat pemerintah apabila terjadi penyimpangan dalam kepemerintahannya. Dari tugas tersebut dapat dibenarkan Upaya jaksa dalam menyelesaikan sengketa dengan jalan litigasi dan non litigasi, sama halnya dengan lembaga hisbah dalam melakukan penuntutan dan pemanggilan para pihak untuk diselesaikan secara damai.

\section{Daftar Pustaka}

Agus, Suryadi, et al. Optimalisasi Peran Datun Kejaksaan dalam Penegakan Hukum. Pusat penelitian dan Pengembangan Kejaksaan RI, 2004.

Aripin, Jaelani. Peradilan Agama dalam Bingkai Reformasi Hukum di Indonesia. Jakarta: Kencana Prenada Media Group, 2008.

Azra, Azyumardi. Ensiklopedi Islam. Jakarta: PT Ichtiar Baru Van Hoeve, 2005.

Departemen Agama RI. Al-Qur'an dan Terjemahannya. Bandung: Syaamil Al-Qur'an, 2007.

Djalil, A Basiq. Peradilan Islam. Jakarta: Amzah, 2012. 
Halim, Abdul dan Icuk Rangga Bawono. Pengelolaan Keuangan Negara-Daerah: Hukum, Kerugian Negara, Dan Badan Pemeriksa Keuangan. Yogyakarta: UPP STIM YKPN, 2011.

Iqbal, Muhammad. Figh Siyasah Kontekstualisasi Doktrin Politik Islam. Jakarta: Gaya Media Pratama, 2001.

Kusumastuti, Ely. "Fungsionalisasi Kewenangan Kejaksaan dalam Bidang Perdata". Thesis, Semarang: Universitas Diponogoro, 2002.

Mawardi (al-), Imam. Al-Ahkam As-Sultaniyyah, Hukum-hukum Penyelenggara Negara dan Syariat Islam. Jakarta: PT Darul Falah, 2006.

Mukhlas, Oyo Sunaryo. Perkembangan Peradilan Islam dari Kahin di Jazirah Arab ke Peradilan Agama di Indonesia. Bogor: Ghalia Indonesia, 2011.

Nabhani (An-), Taqyuddin. An-Nidlam Al-Iqtishadi Fil Islam. diterjemahkan oleh Moh. Maghfur Wachid, Membangun Sistem Ekonomi Alternatif Perspektif Islam, Surabaya: Risalah Gusti, 1996.

Naning, Ramdlon. "Penyelesaian Sengketa Dalam Islam, Peran Badan Arbitrase Syariah Nasional dan Kewenangan Pengadilan Agama Dalam Menyelesaikan Sengketa Ekonomi Syariah", Artikel, 06 Spetember 2008.

Prakoso, Djoko. Eksistensi Jaksa di Tengah-Tengah Masyarakat. Jakarta: Ghalia Indonesia, 1985.

Sevilla, Consuelo G. Pengantar Metode Penelitian. Jakarta: UI Press, 1993.

Shiddieqy (Ash), Teungku Muhamad Hasbi. Peradilan dan Hukum Acara Islam. Semarang: PT Pustaka Rizki Putra, 1997.

Taimiyah, Ibnu. Tugas Negara Menurut Islam. Yogyakarta: Pustaka Pelajar, 2004.

Tutik, Titik Triwulan. Hukum Tata Usaha Negara dan Hukum Acara Peradilan Tata Usaha Negara Indonesia. Jakarta: Kencana Prenada Media Group, 2011. 
Waluyo, Bambang. Penelitian Hukum dalam Praktek. Jakarta: Sinar Grafika 1996.

Widjaja, Gunawan. Pengelolaan Harta Kekayaan Negara, Suatu Tinjauan Yuridis. Jakarta: PT Raja Grafindo Persada, 2002.

Yahya, Al-Imam Abu Zakariya. Riyadussalihin. Al-Haramain, 2005.

Kejaksaan RI dalam http://www.kejaksaan.go.id/tentang kejaksaan.php?id=3, diakses 15 Februari 2013.

Nasution, Dhani. dalam http://dedoubleyou.wordpress.com /2013/02/15/strategi-pengelolaan-barang-milik-negaradaerahiii/, 15 Februari 2013.

Kitab Undang-undang Hukum Acara Perdata

Lembaran Negara Republik Indonesia No 67 (26 Juli 2004) tentang UU Kejaksaan No. 16 Tahun 2004

Lembaran Negara Republik Indonesia (28 April 2003) tentang UU Keuangan Negara No 17 tahun 2003.

Lembaran Negara no 5 tahun 2004 (14 januari 2004) tentang Undang-undang Perbendaharaan Negara No 1 tahun 2004.

Lembaran Negara Republik Indonesia, No.104 tahun 1960 (24 september 1960) Undang-undang Republik Indonesia tentang Peraturan Dasar Pokok-Pokok Agraria, No. 5 Tahun 1960.

Peraturan Presiden Republik Indonesia No. 38 Tahun 2010 tentang Organisasi dan Tata Kerja Kejaksaan Republik Indonesia.

Undang-undang Dasar Republik Indonesia Tahun 1945. 